\title{
AS ARCADAS RECEBEM A PRIMEIRA DIRETORA, EM SEUS 171 ANOS JURÍDICOS
}

\author{
Antonio Augusto Machado de Campos Neto \\ Chefe do Serviço Técnico de Imprensa
}

Aos 10 de agosto de 1998 foi recebida solenemente pela Congregação de Professores da Faculdade de Direito da Universidade de São Paulo o seu $37^{\circ}$ Diretor, no caso em ineditismo uma Diretora, a eminente Dra. Ivette Senise Ferreira, professora titular de Direito Penal desta Casa.

Cumpre salientar que, como sucessora do tenente-general José Arouche de Toledo Rendon, nomeado por decreto de 13 de outubro de 1827, a professora titular de Direito Penal, Ivette Senise, é a primeira mulher a ocupar o cargo da Diretoria desta Academia, que completa 171 anos no roteiro de suas tradições e na consecução de seus altos objetivos, a serviço da sociedade e da própria Universidade de São Paulo.

Nascida em Catanduva, São Paulo, aos 12 de setembro de 1934, é filha de Alcides Senise e Júlia de Carvalho Senise. Foi casada com o professor doutor Manoel Gonçalves Ferreira Filho e é mãe de quatro filhas: Beatriz, Mônica, Marta e Lígia. A elas e aos netos sempre compartilhou o mesmo amor que dedicou a esta Escola.

Uma vez comunitária a Universidade, cuja premissa maior é a de que todos que para ela convergem se sentem chamados por uma vocação intelectual, a professora Ivette Senise Ferreira ingressou nas Arcadas no ano de 1953, graduandose em 1957. Realizou, em seguida, de 1958 a 1959, o curso de pós-graduação em Direito Penal na Faculdade de Direito da Universidade de Paris.

Possui curso de Especialização em Criminologia, Paris; em Organizações Internacionais; em Direito Internacional Privado; em História das Idéias Políticas; em Direito Constitucional Comparado. Realizou o curso de Doutorado de 1976 a 1981. É poliglota, falando fluentemente o inglês, o francês, o italiano e o alemão. Lecionou Introdução à Ciência do Direito na Faculdade de Direito da Pontifícia Universidade Católica de São Paulo, de 1969 a 1973 e Direito Penal, como professora titular, na Faculdade de Direito das Faculdades 
Metropolitanas Unidas de São Paulo, de 1984 a 1988. É professora titular de Direito Penal, nesta Escola, desde 1993

A querida mestra participou, até o ano de 1998, de cerca de 42 bancas examinadoras de Mestrado e Doutorado e de cerca de dez comissões de seleção dos exames de ingresso no Curso de Especialização desta Faculdade e das de exames de revalidação de diplomas, de exames de seleção e da Comissão Julgadora do processo seletivo para preenchimento de vaga de Professor Doutor. Em outras instituições, como a PUC, Mackenzie, Universidade de Goiás, a doutora Ivette Senise Ferreira esteve presente também em dez bancas examinadoras de Mestrado e Doutorado. Participou de congressos, seminários, mesas-redondas e painéis, simpósios, jornadas, encontros semanais, seminários e cursos extra-curriculares, palestras e conferências que, se fôssemos enumerá-los, necessitaríamos mais de 25 laudas, conforme o próprio currículo da dedicada professora se apresenta.

Em participação de colegiados, a nova Diretora participou como membro de 22 instituições, destacando-se a da Comissão de Cultura, Extensão Universitária e de Pesquisa da FDUSP; do Conselho Técnico do Centro de Recursos Humanos da Administração Penitenciária do Estado de São Paulo, do Conselho Nacional da Federação das Associações de Mulheres de Negócios e Profissionais do Brasil, do Conselho Estadual de Política Criminal e Penitenciária do Estado de São Paulo.

Integrou várias comissões, destacando-se a do Grupo de Trabalho, nomeada pelo governador do Estado de São Paulo, Paulo Egydio Martins, em 1976, para elaborar estudos com vistas à implantação de uma Escola de Administração Penitenciária. Em 1993, integrou a Comissão de Juristas, instituída por decreto, para elaborar o projeto de Código Ambiental Brasileiro. Em Paris, no ano de 1995, integrou a International Working Group, instituído pela Unesco, em conjunto com a Fundação Cousteau, para a implantação das Cátedras Internacionais de Ecotecnia.

Durante onze anos foi advogada militante em São Paulo e a tese intitulada A Tutela Penal do Patrimônio Cultural, uma obra completa do Direito Ambiental, levou-a, com louvor, à titularidade nesta Academia de Direito. Sendo a tese de doutoramento O Aborto Legal, apresentada à FDUSP, em 1982, até hoje consultada por professores e alunos. São mais de 28 artigos publicados em revistas especializadas, nacionais e internacionais, destacando-se o Rapport sur "Les Crimes de L'Informatique au Brésil" publicado no XIII Congresso de Direito Comparado, da Academia Internacional de Direito Comparado, no ano de 1989 em Montreal, 
Canadá e "Os Crimes da Informática" in Estudos Jurídicos em homenagem a Manoel Pedro Pimentel, com coordenação de Rubens Prestes Barra e Ricardo Antunes Andreucci, no ano de 1992, Editora Revista dos Tribunais.

É membro do Instituto Manoel Pedro Pimentel, como sua presidente desde 1996, revivendo o Boletim do Instituto Manoel Pedro Pimentel, que tem feito sucesso entre os juristas criminalistas da Cidade de São Paulo nos seis números publicados.

A nova Diretora foi escolhida a Profissional de Direito do ano de 1994 pela Associação Brasileira das Mulheres de Carreira Jurídica, porque "jamais esqueceu a condição de mulher atuante e combativa", como assevera Ada Pellegrini Grinover em discurso proferido à titular no ano de 1994, e cujos méritos, inclusive, foram enaltecidos naquele ano por outra mulher que sempre abrilhantou nossa Faculdade, a professora doutora Esther de Figueiredo Ferraz.

Sempre preocupada com instrumentos jurídicos de proteção contra a crescente degradação dos bens e valores naturais, a querida mestra viajou muito pelo planeta, considerando o Taj Mahal, na Índia, "um dos espetáculos mais lindos, em edificação, que meus olhos presenciaram"

Nesta conquista de láurea após láurea, a titular de Direito Penal fez refulgir aos ecos do Salão Nobre, cuja platéia a aplaudiu de pé, nomes como Hannah Arendt, Esther de Fiqueiredo Ferraz, Ada Pellegrini Grinover, as escritoras Simone de Beauvoir, Maria Antonia Palla, as estadistas Golda Meir, Indira Gandhi, Margareth Thatcher e Andréa Mustafa, primeira acadêmica a presidir o Centro Acadêmico XI de Agôsto, dentre outras, colocando-as na vanguarda de como as mulheres se emanciparam e tiveram destaque nestes últimos anos. Todavia, a mesma platéia estava ciente de que a oradora, que tomava posse naquele dia, é uma mulher ocupada mas que encontra tempo para tudo, professora, mãe, pesquisadora, orientadora e, acima de tudo, humana, o que fará com que a sua gestão, com certeza, seja uma das melhores na galeria dos Diretores desta Instituição Jurídica.

Na solenidade da posse, a professora Ivette Senise Ferreira foi saudada pelo professor e embaixador Celso Lafer, titular do Departamento de Filosofia. Integraram a Mesa-de-Recepção, o Magnífico Reitor, professor Jacques Marcovitch, a secretária-geral da Reitoria, professora Lor Cury, o ex-Diretor, professor Álvaro Villaça Azevedo, a vice-Diretora, professora Odete Medauar, o secretário da Segurança Pública, José Afonso da Silva, o secretário da Justiça, Belisário Santos 
Júnior, o secretário dos Negócios Jurídicos da Prefeitura, professor Edvaldo Pereira de Britto e o doutor Edevaldo Alves da Silva, secretário de Governo da Prefeitura. 